\title{
Walter Stephens. Giants in Those Days: Folklore, Ancient History and
} Nationalism. Lincoln and London: University of Nebraska Press, 1989. Pp. xii, 456.

Walter Stephens argues in this bulky and important contribution to Rabelais studies that the giant Gargantua was not a timeless figure of folklore as Bakhtin and nationalistic French scholars of an earlier generation held, but, in line with Susan Stewart's speculations, an already commodified product of early book publishing for an urban audience. Stephens goes on to locate a serious Renaissance interest in gigantology among genealogical apologists like Annius of Viterbo, who made spurious claims of Noachic origin to satisfy the hegemonic ambitions of powerful ruling families. Jean Lemaire de Belges in the Illustration and Symphorien Champier continue the apologetic tradition, mutatus mutandis, in the name of French ascendancy. Lemaire's giants, like Annius', of necessity embody not the alterity of brute power and wildness, but, anticipating Rabelais' humanist and evangelical giants, who are described as creators, guardians and transmitters of technology and high culture. The jolly genealogical giant runs afoul, however, of theological practices (whose outlines emerge less clearly in Stephens' study) which perforce dealt with Old Testament giants as the generational links of Biblical history were mapped out, especially as they impinged on the genealogy of Christ.

Stephens asserts that Rabelais was familiar with the genealogical claims of Annius and Lemaire by virtue of the prominence accorded to the mock genealogy of the eponymous giant in Pantagruel, although Rabelais' copious text nowhere shows concrete evidence of borrowing from these putative sources. The non-genealogical, but decidedly gigantic Chroniques Gargantuines, which Rabelais' narrator Alcofrybas appropriates and derides in the Pantagruel prologue, purportedly serve, so Stephens would have it, as a metaphor for Annian pretentions to scripturality which Rabelais condemns. Why then should Rabelais not be more open about the "real butt" of his satire? If Lemaire's Gallic pseudo-history was too close to home, surely Annius' Etruscan fabulations were fair and safe game. Were there no other texts, whether popular, historical or pious that distorted Biblical genealogy or made claims of scripturality in order to legitimate a cause? Is the key term of the debate "giants" or "veracity" and, if the latter, what is the relative weight given to allegorical as opposed to literal truth? Is Rabelais perhaps not taking satirical aim less at a specific work or set of works than at a certain kind of reading? In attempting to establish a serious intellectual pedigree for Rabelais' good giants, I am not sure whether Stephens does not step into an Annian quagmire of his own. His argument runs up against both Edwin Duval's recent claim of serious Christological typology underlying Pantagruel's gigantic genealogy and the outright patriotic royalism of Gargantua. Stephens is aware of these objections and others, which he meets head on - if anything, there is too much old-fashioned scholarly skirmishing in his pages - so the reader may have the pleasure of adjudicating these quarrels herself. 
In the course of his richly detailed and learned argument, Stephens makes some telling points: the untrustworthiness of Alcofrybas, for example, which supports Gérard Defaux's claims of a sophistical narrator; the typological role played by Noah, overlooked by Duval; the presence of Nimrod's name, nim broth in Panurge's Babelic discourse, etc. Above all, Stephens raises larger, highly relevant, but neglected questions about Renaissance historiography, popular culture, the quest for origins, nationalism, power and legitimacy that should challenge Rabelaisian scholars for some time. (The large green finger on the rear inner flap of the dust jacket - constantly juxtaposed to the real flesh of my puny finger - is a wonderfully unsettling bit of authentic pop-Rabelaisian humour.)

PHILIP R. BERK, University of Rochester 